\title{
INNOCENT SUFFERING IN EGYPT
}

\author{
Daniel P. Bricker
}

\begin{abstract}
Summary
There are many studies exploring the idea of innocent suffering and the concept of theodicy as it occurs in the literature of ancient Mesopotamia and Israel, but this is not so much the case with ancient Egyptian literature. This article will explore this matter in regard to ancient Egyptian documents. The point is to discover what factors in Egyptian culture led to the exclusion of theodicy and the idea of innocent suffering from their world view and literature.
\end{abstract}

\section{Introduction: The Purpose of the Study}

Recent scholarship has accepted the idea that the ancient Near East had a common view regarding innocent suffering that is sometimes discussed under the heading of theodicy. This topic is more prominent in discussions regarding Mesopotamian and Israelite literaturel but it leads one to ask how the subject of innocent suffering was approached in ancient Egypt. The purpose of this article is to examine the reasons why theodicy, as we understand the term today, ${ }^{2}$ is virtually absent from ancient Egyptian literature. The literature of ancient Israel, while certainly important in the overall discussion of theodicy, will not be mentioned in the current study except in passing.

Wolfram von Soden has listed four basic elements which must be present for the question of theodicy to be raised:

I For discussion of Mesopotamian literature see G.L. Mattingly, 'The Pious Sufferer: Mesopotamia's Traditional Theodicy and Job's Counsellors', in W.W. Hallo, B.W. Jones, and G.L. Mattingly, ed., The Bible in the Light of Cuneiform Literature (Lewiston: Mellen, 1990), 313-18; and my 'Innocent Suffering in Mesopotamia', TynB 51 (2000), 193-214. For discussion of Israelite literature see J.L. Crenshaw, 'Theodicy', Anchor Bible Dictionary 6.444-47.

2 Theodicy is an attempt to defend divine justice in the face of aberrant phenomena that appear to indicate a deity's indifference or hostility toward virtuous people; see Crenshaw, 'Theodicy', 444. 
(1) a clear sense of right and wrong, so that a sufferer could reasonably claim to be suffering undeservedly;

(2) significant individual worth, so that personal suffering must be justified;

(3) minimal competition within the godhead or pantheon, so that suffering cannot be blamed on one deity due to human loyalty to another; and

(4) a limited view of judgment in the afterlife. ${ }^{3}$

A lack of any one of these elements relieves the tension which leads to a theodicy since the principle of equitable or just retribution is negated or qualified. If these four factors are present the question of suffering may not be answered but it allows the deity to be relieved of responsibility for suffering and therefore questions of divine injustice no longer apply. 4

After a look at Egypt's religious background, four documents will be examined in order to determine the source of evil and suffering, and what, if any, responsibility was ascribed to the gods. Then some concluding comparisons will be made between Mesopotamian and Egyptian literature regarding the treatment of innocent suffering.

\section{A Brief Look at Egypt's Religious Background}

In Egypt, as in most ancient societies, religion was a dominating force. ${ }^{5}$ The focal point of Egyptian religion was the pharaoh, who was viewed as divine and associated with Horus, ${ }^{6}$ though his divinity was not on the same level as the non-human gods of the pantheon. ${ }^{7}$ Rather than belief in a divine king it would be more accurate to say they

3 See W. von Soden, 'Das Fragen nach der Gerechtigkeit Gottes im Alten Orient', Mitteilungen der deutschen Orient-Gesellschaft 96 (1965), 46; cf. also J.H. Walton, Ancient Israelite Literature in Its Cultural Context (rev. ed.; Grand Rapids: Zondervan, 1990), 180.

4 Walton, Ancient Israelite Literature, 180.

5 J.K. Hoffmeier, 'Egyptians', in A.J. Hoerth, G.L. Mattingly, and E.M. Yamauchi, ed., Peoples of the Old Testament World (Grand Rapids: Baker, 1994), 283.

6 H. Frankfort, Kingship and the Gods (Chicago: University of Chicago, 1948; repr. Phoenix Books, 1978), 15-50.

7 See G. Posener, De la divinité du pharaon (Cahiers de la Société Asiatique 15; Paris: Imprimerie Nationale, 1960); and E. Hornung, Conceptions of God in Ancient Egypt: The One and the Many (tr. J. Baines; Ithaca: Cornell University, 1982), 141-42, for a balancing view of the recent tendency to 'over-divinise' the pharaohs. 
believed in the divine office of kingship. ${ }^{8}$ The king functioned as the ultimate high priest, who built temples and saw to their maintenance. ${ }^{9}$

Because Egyptian beliefs were never consolidated or systematised there was no single 'Egyptian religion'. Beliefs remained fluid, even during the historical period, and they had no one 'sacred book', making it difficult to say what was believed by whom. ${ }^{10}$ It is likely that the existing texts relate to a small group of the social elite showing little direct evidence for the beliefs and attitudes of the rest of the people. ${ }^{11}$

The average person, compared with royalty and priests, had limited contact with the deities. One of those points of contact was when periodic festivals were observed. There were small chapels (khenu) of the gods in Memphis during the New Kingdom era and following. And there were chapels operated by lay priests in Deir el-Medineh, where hundreds of small offering steles and votive objects have been found. ${ }^{12}$ The votive objects show that the same deities worshipped in the state religion were also revered by ordinary individuals. ${ }^{13}$ The gods were purified, fed, clothed and praised on a daily basis but this was done by the privileged and by those attached to the temple cult, not the ordinary individual..$^{14}$ It may be because of the limited access to or exclusion from state temples that the small cult centres arose close to towns and villages in the Old and Middle Kingdoms. ${ }^{15}$ Before the New Kingdom there were expressions of devotion to a particular god on the part of certain individuals, but only a few of these have been recovered. ${ }^{16}$ From the New Kingdom on, there are

8 J.G. Griffiths, The Divine Verdict: A Study of Divine Judgement in the Ancient Religions (Leiden: Brill, 1991), 162-63.

9 Hoffmeier, 'Egyptians', 283.

10 D.P. Silverman, 'Divinity and Deities in Ancient Egypt', in B.E. Shafer, ed., Religion in Ancient Egypt (Ithaca: Cornell University, 1991), 12; see also in the same volume J. Baines, 'Society, Morality, and Religious Practice', 123.

11 Baines, 'Society, Morality, and Religious Practice', 124.

12 A.I. Sadek, Popular Religion in Egypt During the New Kingdom (Hildesheimer Ägyptologische Beiträge 27; Hildesheim: Gerstenberg, 1987), 79-83; Baines, 'Society, Morality, and Religious Practice', 184-85; Hoffmeier, 'Egyptians', 284.

13 Hoffmeier, 'Egyptians', 284.

14 See H. te Velde, 'Theology, Priests, and Worship in Ancient Egypt', in J.M. Sasson, ed., Civilizations of the Ancient Near East (4 vols.; New York: Scribner, 1995), 3.1741-45; Baines, 'Society, Morality, and Religious Practice', 126-27.

15 Sadek, Popular Religion in Egypt, 5-10; Hoffmeier, 'Egyptians', 284.

16 See P. Vernus, 'Études de philologie et de linguistique (II)', Revue d'Égyptologie 34 (1982-83), 115-17. 
many examples of personal piety shown by scarab inscriptions, dreams, oracles, and the meanings of personal names. ${ }^{17}$

The king was an example of how others should conduct their lives. He was 'on earth for ever and ever, judging humanity and propitiating the gods, and setting order in place of disorder. He gives offerings to the gods and mortuary offerings to the spirits (the blessed dead).' 18

In addition to the king, ma 'at was also a very important concept in Egyptian religion. The meaning of the word incorporates ideas such as truth, harmony and justice. ${ }^{19} \mathrm{It}$ is the 'right' or correct behaviour in any given circumstance. ${ }^{20}$ Old Kingdom texts speak of 'doing $m a$ ' $a t$ ' or 'speaking $m a$ 'at', in contrast with the opposites 'wrong' and 'falsehood', giving the clear conclusion that $\mathrm{ma}$ 'at had the meanings 'right' and 'truth' from very ancient times. ${ }^{21}$ In a quotation from The Instruction of Ptahhotep, an Old Kingdom text (before 2200 BC), $m a$ 'at is shown to be equated with a universal standard:

Great is justice (ma' $a t)$, lasting in effect,

Unchallenged since the time of Osiris.

One punishes the transgressor of laws,

Though the greedy overlooks this;

Bareness may seize riches,

Yet crime (iśft) never lands its wares;

In the end it is justice ( $m a$ ' $a t$ ) that lasts,

Man says: 'It is my father's ground.' 22

Miriam Lichtheim says:

17 Baines, 'Society, Morality, and Religious Practice', 174-78.

18 See J. Assmann, Der König als Sonnenpriester: Ein kosmographischer Begleittext zur kultischen Sonnenhymnik (Glückstadt: Augustin, 1970), 17-22; and Baines, 'Society, Morality, and Religious Practice', 128. In this quotation 'order' is $m a$ ' $a t$, a fundamental religious and social concept. 'Disorder' is isft, the opposite of $m a$ 'at, which is associated with the world outside creation.

19 J.D. Ray, 'Egyptian Wisdom Literature', in J. Day, R.P. Gordon, and H.G.M. Williamson, ed., Wisdom in Ancient Israel (Cambridge: CUP, 1995), 20. See also J. Assmann, Ma'at: Gerechtigkeit und Unsterblichkeit im alten Ägypten (Munich: C.H. Beck, 1990) for a detailed study.

20 G.L. Archer and W.S. LaSor, 'Religions of the Biblical World: Egypt', in G. Bromiley, ed., International Standard Bible Encyclopedia (4 vols.; Grand Rapids: Eerdmans, 1979-88), 4.107.

21 M. Lichtheim, Maat in Egyptian Autobiographies and Related Studies (OBO 120; Göttingen: Vandenhoeck \& Ruprecht, 1992), 18. The literature on ma'at is enormous; see W. Helck, 'Maat', in W. Helck and E. Otto, ed., Lexikon der Ägyptologie (7 Bände; Wiesbaden: O. Harrassowitz, 1975-92), 3.1110-19; and A. Volten, 'Der Begriff der Maat in den ägyptischen Weisheitstexten', in (no ed.) Les Sagesses du Proche-Orient ancien (Paris: Presses Universitaires de France, 1963), 73-101.

22 M. Lichtheim, Ancient Egyptian Literature (3 vols.; Berkeley: University of California, 1973-80), 1.64, maxim 5. 
[M]an did Maat because it was 'good' and because 'the god desires it'. It was the principle of right order by which the gods live, and which man recognized as needful on earth and incumbent upon them..$^{23}$

This principle of cosmic dimensions regulated the functioning of nature, society, and an individual's life. But it was not a mechanical, impersonal principle. It meant veracity or fair dealing. ${ }^{24} \mathrm{Ma}$ 'at was personified as the daughter of the sun god and worshipped as a goddess, having both temple and cult dedicated to her honour. ${ }^{25}$

Due to the multiple systems of theology in Egypt it is difficult to provide a basic background to the discussion. Regarding their beliefs in creation, each cosmogony was characterised by a main creator deity who generated associated gods and goddesses. ${ }^{26}$ The enormous time span over which Egyptian literature emerges causes it to show some variety and change over the centuries. Thus we should not expect to see consistency throughout the literature of Egypt, nor see concepts viewed in the same way in the different theological systems. ${ }^{27}$ Regarding wisdom literature, Egyptian wisdom writings were never considered sacred, unlike Israelite wisdom literature. ${ }^{28}$

Egyptian deities were portrayed in a large number of forms, ranging from animal to human, to a combination of both. ${ }^{29}$ The gods often exhibited human emotions and engaged in human activity. They thought, spoke, dined, travelled by boat, had a sense of humour, and some even drank to excess. ${ }^{30}$ The gods were created beings, hence not eternal. The Egyptian calendar contained days set aside to mark birthdays of many of their gods. ${ }^{31}$ The gods were also subject to death

23 Lichtheim, Maat, 19.

24 Lichtheim, Maat, 37.

25 E.F. Wente, 'Egyptian Religion', in Anchor Bible Dictionary, 2.410; Hornung, Conceptions of God, 75.

26 Silverman, 'Divinity and Deities in Ancient Egypt', 30. See also in the same volume L.H. Lesko, 'Ancient Egyptian Cosmogonies and Cosmology', 88-122; for a more detailed discussion see J.P. Allen, Genesis in Egypt: The Philosophy of Ancient Egyptian Creation Accounts (Yale Egyptological Studies 2; New Haven: Yale University, 1988).

27 See J.A. Gladson, 'Retributive Paradoxes in Proverbs 10-29' (Ph.D. diss., Vanderbilt University, 1978), 80, in this regard. Despite the different theological systems there was very little fluctuation in the way ma 'at was viewed, according to Lichtheim, Maat, 97.

28 Wente, 'Egyptian Religion', 410.

29 Silverman, 'Divinity and Deities in Ancient Egypt', 19-23.

30 Silverman, 'Divinity and Deities in Ancient Egypt', 15-16.

31 P. Kaplony, 'Geburtstage (Götter)', in Lexikon der Ägyptologie, 2.477-79. 
and rebirth, though not always in the mortal sense. ${ }^{32}$ Some texts mention a limited and fixed life span for deities, and the story of The Blinding of Truth by Falsehood refers to 'the god's tomb' ${ }^{33}$ The resurrection of Osiris is mentioned frequently in the Coffin Texts, ${ }^{34}$ and $\mathrm{Re}$, the king of the gods, died symbolically every sunset and was reborn the next day. ${ }^{35}$

Since the gods participated in the afterlife it was only natural to see this as a precedent for human existence as well. ${ }^{36}$ At first, only the king and society's elite were mummified but after the Old Kingdom this privilege was extended to others. ${ }^{37}$ It is a preoccupation with life after death that provides the most insight into the Egyptian view of suffering.

As for the practice of the medical arts in ancient Egypt, there is ample evidence of physicians who based their practice on empiricoscientific principles as far back as the Old Kingdom. ${ }^{38}$ They show an advanced level of knowledge regarding human anatomy, and in some cases are surprisingly devoid of magic or religious jargon. ${ }^{39}$ This is in contrast to Mesopotamian medicine, which seems to have been based more on superstition than science. 40

32 Silverman, 'Divinity and Deities in Ancient Egypt', 29; cf. Wente, 'Egyptian Religion', 410.

33 S. Morenz, Egyptian Religion (tr. A. Keep; Ithaca: Cornell University, 1973), 24-25; Hornung, Conceptions of God, 151-65.

34 Hornung, Conceptions of God, 152-53; e.g., Coffin Text spells 16, 17 and 148 in A. de Buck, The Egyptian Coffin Texts (7 vols.; Chicago: University of Chicago, 1935-61), 1.47-53; 2.209-226.

35 Silverman, 'Divinity and Deities in Ancient Egypt', 29.

36 Wente, 'Egyptian Religion', 411.

37 See R.B. Finnestad, 'The Pharaoh and the "Democratization" of Post-mortem Life', in G. Englund, ed., The Religion of the Ancient Egyptians: Cognitive Structures and Popular Expressions (Uppsala: Acta Universitatis Upsaliensis, 1989), 89-93; and in the same volume, J.P. Sørensen, 'Divine Access: The Socalled Democratization of Egyptian Funerary Literature as a Socio-cultural Process', 109-123.

38 See M.L. Brown, Israel's Divine Healer (Grand Rapids: Zondervan, 1995), 4142 , and his attending bibliography.

39 Brown, Israel's Divine Healer, 41-42. This is not to say that no magical rites were practised; see J.F. Borghouts, Ancient Egyptian Magical Texts (Leiden: Brill, 1978); and R.K. Ritner, The Mechanics of Ancient Egyptian Magical Practice (Chicago: Oriental Institute, 1992).

40 According to A.L. Oppenheim, Ancient Mesopotamia: Portrait of a Dead Civilization (rev. ed. E. Reiner; Chicago: University of Chicago, 1977), 224, who observed that prescribed medical treatment occurs rarely and is not medical but magical. The names of diseases are not medical but usually point to the deity or demon that caused them. 
The following study will suggest three reasons why Egyptian literature does not address the issue of theodicy. The three reasons are that the gods are rarely blamed for human suffering; that all suffering is due to a perversion of the Egyptian concept of ma'at; and that inequity or injustice will be rectified in the afterlife.

\section{The Gods Are Rarely Blamed for Human Suffering}

The gods are rarely blamed or questioned for the upheavals in human society. ${ }^{41}$ In Egypt the idea of evil overlapped to a great extent with that of disorder. ${ }^{42}$ This promoted a 'don't-rock-the-boat' attitude, and kept the ruling group in power.

In a Middle Kingdom text there is an apologia of the creator god, who distances himself from human wrongdoing, saying:

I made every man like his fellow.

I did not ordain that they do wrong (isft, 'disorder').

It was their desires that damaged what I had said. ${ }^{43}$

The last line speaks of the damage to the created world (brought into existence by the creative word of the god?) caused by the desires of humanity. The Egyptian gods simply cannot be made responsible for evil, since the gods are neither immortal nor omnipotent. Evil is inherent in the non-existent and hence older than the gods. Evil is the fault of human beings, who are seen as leaving space for wrongdoing in their hearts (the organ that determines action). Since the gods are unable to transcend the boundaries of the existent there is no need to justify a deity in the face of evil and suffering. ${ }^{44}$ As Baines says:

The creator is not responsible for the origin of evil. He cares so much for people's well-being that 'he has built himself a shrine around them; when they weep he hears' (I. 135). This image of tears relates to the origin of human beings. A wordplay found in the creator's apologia and in other

41 R.J. Williams, 'Theodicy in the Ancient Near East', in J.L. Crenshaw, ed., Theodicy in the Old Testament (Philadelphia: Fortress, 1983), 47.

42 Baines, 'Society, Morality, and Religious Practice', 163; and R. Grieshammer, 'Gott und das Negative nach Quellen der ägyptischen Spätzeit', in W. Westdorf, ed., Aspekte der spätägyptischen Religion (Wiesbaden: Harrassowitz, 1979), 7992.

43 De Buck, Coffin Texts, 7.464a-b. Cf. R.B. Parkinson, Voices from Ancient Egypt (Norman: University of Oklahoma, 1991), 32-34, and the slightly freer rendering of Lichtheim, Ancient Egyptian Literature, 1.131-33.

44 Hornung, Conceptions of God, 212-13. 
sources says that people arose from the creator's tears-an indirect statement that they are born to suffer. ${ }^{45}$

This is quite similar to the Mesopotamian view ${ }^{46}$ in that there was a divine order that regulated society and individual lives (Mesopotamia, $M E$; Egypt, $m a{ }^{\prime} a t$ ) and neither society made blatant accusations of divine injustice, or attributed evil to the gods. Any suggestion of injustice done by a deity was done so only with the greatest caution and circumspection.

\section{Suffering Is Due to Perversion of Ma'at}

Where did evil arise in the Egyptian world view? Part of the answer has already been referred to-the presence of isft, 'disorder'. But there is also a more direct source, that of humans themselves. Some of the texts quoted above have hinted at this. In virtually all of the wisdom or reflective texts human suffering is viewed as a result of the perversion of $m a$ 'at by humans. ${ }^{47}$

Four documents will be examined with reference to these issues. Though the study will not be exhaustive, it is intended to show that the source of evil and suffering almost always lay with humanity's failure to live up to the standards of $m a$ 'at, thus placing the blame on mankind and removing it from the gods.

(1) Admonitions of Ipuwer. This document can be placed in the category of speculative works. ${ }^{48} \mathrm{~K}$.A. Kitchen classifies it as Wisdom and 'Social' Literature. ${ }^{49}$ The beginning of this work is lost, and with it, the setting. In its present form, which is no earlier than the late Thirteenth Dynasty, ${ }^{50}$ the text is in two parts. The study by Fecht suggests that the main body was probably produced between 2180 and

45 Baines, 'Society, Morality, and Religious Practice', 163-64; see de Buck, Coffin Texts, 7.465a, and Hornung, Conceptions of God, 149-50. The wordplay is that the first human ( $r m t$, later $r m t)$ was created from the tear (rmit) of the creator-god.

46 See the discussion and accompanying documentation in my 'Innocent Suffering in Mesopotamia', 195-96.

47 Williams, 'Theodicy', 47.

48 R.J. Williams, 'Egyptian Literature (Wisdom)', in Anchor Bible Dictionary, 2.397 .

49 K.A. Kitchen, 'The Basic Literary Forms and Formulations of Ancient Instructional Writings', in E. Hornung and O. Keel, ed., Studien zu altägyptischen Lebenslehren (OBO 28; Göttingen: Vandenhoeck \& Ruprecht, 1979), 237-40.

50 This document may have been a reaction to the disaster at the close of the Old Kingdom; see D.B. Redford, 'Ancient Egyptian Literature: An Overview', in Civilizations of the Ancient Near East, 4.2233-34. 
$2130 \mathrm{BC} .{ }^{51}$ The second part is a dialogue between Ipuwer and the creator god. 52

Though the situation in this text is not considered historical ${ }^{53}$ it is unusual in that the sage criticises the god for deplorable conditions existing in the land. The king responds to the criticism at the end of the document, and from what remains of the speech it seems that the king places the blame for the adverse conditions on the people themselves. ${ }^{54}$ Even in a text where a god is reproached for allowing people to suffer and conditions to deteriorate, the conventional view is still present, that these conditions are due to actions of people, and the gods cannot be blamed.

(2) Dispute of a Man with His Ba. Dating from the Twelfth Dynasty, this poem is preserved in a single manuscript, of which the first part is missing. ${ }^{55}$ This document has also been known as the 'Dispute over Suicide'. ${ }^{56}$ There are many ways of interpreting this difficult work but the basic facts are communicated as a discussion between 'a man' and his $b a$, or 'soul' .57 This is frequently the translation seen for $b a$ but it has no Semitic equivalent, and 'soul' fails to communicate its salient meaning. The $b a$ is the 'moral essence of a person's motivation and movement, which also enables him or her to be free in the next world'. ${ }^{58}$ It is the personification of the life force that animates the $k h a$ (body). ${ }^{59}$

51 G. Fecht, Der Vorwurf an Gott in den 'Mahnworten des Ipu-wer' (Heidelberg: Carl Winters Universitätsverlag, 1972).

52 Williams, 'Egyptian Literature (Wisdom)', 397-98.

53 Lichtheim, Ancient Egyptian Literature, 1.149-50.

54 Lichtheim, Ancient Egyptian Literature, 1.161-62, n. 29.

55 Lichtheim, Ancient Egyptian Literature, 1.163.

56 J.B. Pritchard, ed., Ancient Near Eastern Texts (3rd ed.; Princeton: Princeton University, 1969), 405-407.

57 R.E. Murphy, The Tree of Life: An Exploration of Biblical Wisdom Literature (New York: Doubleday, 1990), 170. For a discussion of other ways this document has been interpreted see R.J. Williams, 'Reflections on the Lebensmüde', JEA 48 (1962), 49-56.

58 Baines, 'Society, Morality, and Religious Practice', 145. For a summary of Egyptian anthropology see L.H. Lesko, 'Death and Afterlife in Ancient Egyptian Thought', in Civilizations of the Ancient Near East, 3.1763-64; and Wente, 'Egyptian Religion', 2.411.

59 H. Seebass, 'נפכשפ', in G.J. Botterweck und H. Ringgren, ed., Theologisches Wörterbuch zum Älten Testament (8 Bände; Stuttgart: Kohlhammer, 1973-95), 5.533. The $b a$ was often pictured in Egyptian artwork as a migratory stork, or a human-headed bird which flutters over the mummy or near the tomb and may be benefitted by offerings, water or shade; see Archer and LaSor, 'Religions of the Biblical World: Egypt', 4.106; and the picture of a 'soul tree' in C.M. Robeck, 'Soul', in International Standard Bible Encyclopedia, 4.587. 
A brief look at the contents of the work shows a suffering man expressing his longing for death. Angered over this, his $b a$ threatens to leave him. This causes horror to the man, since abandonment by the $b a$ would mean total annihilation instead of the resurrection and eternal bliss which he imagined, and he entreats his $b a$ to stay with him and not oppose him in his longing for a natural death, rather than a suicide. The $b a$ then tells the man that death is a sad business, and that those who have nice tombs are no better off than those who have none. The $b a$ urges the man to stop complaining and enjoy life. The man seems unconvinced, since he closes by deploring the miseries he has to endure, and exalts death and resurrection. In a concluding speech the $b a$ decides to remain with the man. 60

On the subject of the source of evil, the Dispute is silent. The 'second poem of the man' (lines 103-130) cites instances of wrongdoing, greed, criminal activity and alienation, for the current misery the man is enduring. In lines $122-23$ he says:

To whom shall I speak today?

None are righteous,

The land is left to evildoers. ${ }^{61}$

The word translated 'righteous' is based on the root ma 'at. Contrasted to 'the righteous' are 'the evildoers', (irw isft) both words having strong moral connotation. ${ }^{62}$ The poem acknowledges the existence of evil, citing many examples, but nowhere is the question of origin asked with regard to evil. The role of the gods mentioned in the text is judicial, ${ }^{63}$ and the idea that misery in life will be rewarded in a hereafter, where death brings recovery and refreshment, appears in lines $130 \mathrm{ff}^{64}$

The conclusion we come to in examining the Dispute is that the problems of an innocent sufferer are brought on by others who do not observe ma'at.

60 Lichtheim, Ancient Egyptian Literature, 1.163; Murphy, Tree of Life, 170. Williams, 'Egyptian Literature (Wisdom)', 398, sees it as an attack on the traditional costly material provision for the afterlife.

61 Lichtheim, Ancient Egyptian Literature, 1.167.

62 De Buck, Coffin Texts, 4.63a. This is reflected in many of the other translations as well; cf. R.O. Faulkner, 'The Man Who Was Tired of Life', JEA 42 (1956), 29: 'just persons', 'doers of wrong'; W.K. Simpson, ed., The Literature of Ancient Egypt (New Haven: Yale University, 1972), 207: 'just persons', 'doers of wrong'; J.L. Foster, Echoes of Egyptian Voices (Norman: University of Oklahoma, 1992),

17: 'righteous men', 'evil'.

63 Lines 23-31, Lichtheim, Ancient Egyptian Literature, 1.164-65.

64 The 'third poem of the man', Lichtheim, Ancient Egyptian Literature, 1.168. 
(3) Tale of the Eloquent Peasant. This story dates from the Middle Kingdom and was apparently intended as an essay in what the Egyptians considered fine writing. ${ }^{65}$ The text consists of a series of nine poetic speeches framed by narrative 66 in which a humble oasis dweller (not a 'peasant' ${ }^{67}$ ) named Khun-Anup has his goods taken from him by a tenant farmer. When the complaint is brought before the high steward, Rensi son of Meru, he is so impressed with KhunAnup's eloquence that he delays repayment for the lost goods until after the nine speeches are made.

Though it is evident in the poetry and literary devices ${ }^{68}$ that this was an essay showing fine writing, the main emphasis is on the rights of the common individual. ${ }^{69}$ There is no outcry against the gods over the injustices done to Khun-Anup, only a criticism of those who fail to do ma' $a t$, as he tells Rensi:

Do Justice ( $\left.m a^{\prime} a t\right)$ for the Lord of Justice ( $\left.m a^{\prime} a t\right)$, who is the wise perfection of his Justice (ma' $a t$ ).

Reed pen, papyrus, and palette of Thoth all dread to write injustice: when good is truly good, that good is priceless-

But Justice (ma'at) is forever, and down to the very grave it goes with him who does it.

His burial conceals that man within the ground, yet his good name shall never perish from the earth. ${ }^{70}$

The eternality of $m a$ 'at as the standard of right order is shown here, and injustice results when people, especially those in power, do not abide by its standards. Khun-Anup calls in frustration to the high steward, who has remained silent during the entire ordeal:

Do not answer with the answer of silence! do not attack one who does not attack you.

You have no pity, you are not troubled,

You are not disturbed!

You do not repay my good speech which comes from the mouth of $\mathrm{Re}$ himself!

Speak justice (ma'at), do justice (ma'at),

For it is mighty;

It is great, it endures,

Its worth is tried,

It leads to reveredness. ${ }^{71}$

65 Simpson, Literature of Ancient Egypt, 31.

66 Lichtheim, Ancient Egyptian Literature, 1.169.

67 Williams, 'Egyptian Literature (Wisdom)', 398.

68 See Simpson, Literature of Ancient Egypt, 35, n. 11; 37, n. 23; 41, n. 48; etc.

69 Williams, 'Egyptian Literature (Wisdom)', 398.

70 Lines 304-307; this translation is that of Foster, Echoes, 83. 
As the story ends, the high steward Rensi eventually forces the robber to repay Khun-Anup for his losses. Rather than criticise the gods, one of the last things said by Khun-Anup prompting Rensi into action is the threat by the sufferer to plead his case to the god Anubis if Rensi continues his silence:

Here I have been pleading with you, and you have not listened to it.

I shall go and plead about you to Anubis! ${ }^{72}$

For Khun-Anup the problems he experienced were external and social. For the man in the Dispute they were internal and personal. However, both see injustices and suffering resulting from a perversion of $m a$ ' $a t$. As indicated earlier, this concept of cosmic order is similar to the Sumerian $M E$ but with a significant difference. In Mesopotamia the gods are 'wielders of the $M E$ ' 73 whereas in Egypt, pharaoh and the gods exist by $m a$ 'at. ${ }^{74}$ Thus $m a$ 'at has more extensive ramifications in its relation to the realm of the divine. ${ }^{75}$ It was a standard of behaviour that both deities and humans were measured by. ${ }^{76}$ Speaking and doing $m a$ 'at led to success; failing to do so led to isft, disorder. If $m a$ ' $a t$ is to be understood in the sense of harmony, truth and justice, then this has implications for social relationships. Everyone has rights, and those rights carry with them a responsibility for those around them. Individuals were seen as careworthy creations of the gods and this formed the basis for morality. ${ }^{77}$ This is a far cry from the Sumero-Babylonian view that humanity was created to serve the gods, and that justice was a privilege rather than a right. 78

71 Lichtheim, Ancient Egyptian Literature, 1.181. Foster's translation (Echoes, 84) differs slightly but meanings are essentially the same.

72 Lichtheim, Ancient Egyptian Literature, 1.182, the end of the ninth petition.

73 See W.W. Hallo and J.J.A. van Dijk, The Exaltation of Inanna (New Haven: Yale University, 1968), 15, 49-50; and W.W. Hallo and K. Lawson Younger, ed., The Context of Scripture (3 vols.; Leiden: Brill, 1997-99), 1.518-22 for a recent translation of Inanna.

74 Frankfort, Kingship and the Gods, 158, 278; Hornung, Conceptions of God, 213-14.

75 Walton, Ancient Israelite Literature, 91.

76 It is still a matter of discussion whether the concept of $M E$ was as central to Mesopotamian society as ma'at was to Egypt. See H.H. Schmid, Wesen und Geschichte der Weisheit (BZAW 101; Berlin: Töpelmann, 1966), 115-18, for a survey of the question.

77 J.A. Wilson, 'Egypt', in H. Frankfort et al., The Intellectual Adventure of Ancient Man (Chicago: University of Chicago, 1946; repr. Phoenix Books, 1977), 82, 108-109.

78 T. Jacobsen, 'Mesopotamia', in Intellectual Adventure of Ancient Man, 207208. 
(4) Teaching of Amenemhet. This purported communication of an assassinated king to his son and successor has only slight bearing on this study. It is mentioned due to its unique position on the subject. It has no religious aspect to it, and nothing is said about ma 'at. ${ }^{79}$ The main message of the instructions is 'trust no one': 80

Trust not a brother, know not a friend,

Make no intimates, it is worthless.

When you lie down, guard your heart yourself,

For no man has adherents on the day of woe. ${ }^{81}$

Amenemhet then gives evidence why this advice should be taken:

I gave to the beggar, I raised the orphan,

I gave success to the poor as to the wealthy;

But he who ate my food raised opposition,

He whom I gave my trust used it in a plot. ${ }^{82}$

The speaker claims he did what the kings of Egypt were supposed to do, yet within his palace a plot was made which eventually led to his murder. In the concluding two lines of this section of poetry Amenemhet encourages his son to learn the lessons he has to offer:

If one fights in the arena forgetful of the past,

Success will elude him who ignores what he should know.

This document is the only known specimen of its kind, yet over seventy copies or portions of it have been recovered. ${ }^{83}$ It is a misanthropic work, characterised by cynicism and bitterness. In both poetical sections Amenemhet asserts that the good he did for his subjects and the country was repaid with betrayal and ultimately murder. Amenemhet claims to have suffered undeserved violence. In his advice no blame is ascribed to the gods, only untrustworthy people are warned against.

The political function of this essay was to validate the succession to the throne of Sesostris I, the son of Amenemhet. ${ }^{84}$ It was probably

79 W.L. McKane, Proverbs: A New Approach (OTL; Philadelphia: Westminster, 1970), 85.

80 Murphy, Tree of Life, 165; McKane, Proverbs, 84.

81 Lichtheim, Ancient Egyptian Literature, 1.136.

82 Lichtheim, Ancient Egyptian Literature, 1.136.

83 Lichtheim, Ancient Egyptian Literature, 1.135, observes that the subject of regicide conflicted too strongly with the dogma of divine kingship for several works of this sort to be produced, yet Simpson (Literature of Ancient Egypt, 193) says that the large number of copies or portions recovered indicate its popularity. Note also the comment of McKane (Proverbs, 83) in this regard.

84 Simpson (Literature of Ancient Egypt, 193) calls it a blatant work of political propaganda designed to validate the new king. 
written by a creative royal scribe in the employ of Sesostris I who showed a lot of imagination, but few modern scholars take this work at face value. This forces any analysis of the work to be careful not to take it as a historical record, although the attitudes displayed toward royal advisors and other people are informative.

\section{Inequity or Injustice Was Often Rectified in the Afterlife}

When rewards and punishments could be projected into a postmortem existence the problem of injustice and innocent suffering becomes a less vital concern. ${ }^{85} \mathrm{~A}$ culture which believes that there is a judgement after death for all individuals plays down the need for retribution and reward in this life since all scores will be settled in the next life and it is never too late for righteousness to be rewarded.

\section{An Assessment of Egyptian Literature in Regard to Theodicy}

What conclusions now seem likely regarding these documents in light of the comparison with von Soden's elements of theodicy?

\section{A Clear Sense of Right and Wrong}

To do right was to conform to ma 'at. No one could ever exhaust the knowledge of ma 'at completely nor conform to ma 'at totally; hence a certain amount of disorder in an individual's life and in society was expected. For the Egyptians $m a$ 'at was seen as 'doing good', and becoming cognisant of $m a$ 'at was based on instruction and observation or perception and insight. ${ }^{86}$ The funerary inscriptions show their claims to have done certain things or abstained from other activities in the attempt to gain a favourable verdict in the judgement. ${ }^{87}$ Morenz says these inscriptions show us that

...the Egyptians possessed general maxims of conduct, such as the need to avoid inflicting pain upon one's fellow beings, but did not attempt to describe exhaustively all the possible wicked actions whereby this could be done. They may be said to have had an ethic of an attitude of mind, which obliges men themselves to apply to the concrete circumstances the general

85 Williams, 'Theodicy', 48. For a basic discussion of the afterlife in Egypt see Silverman, 'Divinity and Deities in Ancient Egypt', 46-49; in more detail, H. Kees, Totenglauben und Jenseitsvorstellungen der alten Ägypter (Berlin: Akademie, 1977).

86 Morenz, Egyptian Religion, 123.

87 Morenz, Egyptian Religion, 134. 
moral maxim that one should show consideration for one's fellows. Thus Egyptian ethics are oriented toward commission and omission, but also toward facts and toward mental attitudes. ${ }^{88}$

One may get a glimpse into Egyptian ethics and morals by examining the Negative Confessions (Book of the Dead, chapter 125), where a list of actions or attitudes was denied in order to achieve a favourable judgement in the afterlife. ${ }^{89}$

Compared with Mesopotamia, evidence for a written law code is sparse for ancient Egypt. ${ }^{90}$ Morals were conveyed in five types of literary sources: (1) instructions in wisdom; (2) autobiographies; (3) declarations of innocence in the Book of the Dead, chapter 125; (4) priestly prohibitions and declarations inscribed on temple doors; and (5) imaginative tales that conveyed moral lessons. ${ }^{91}$ Individuals knew their personal conduct would have to be accounted for and weighed against $m a$ 'at in the judgement.

\section{Significant Individual Worth}

The Egyptians considered themselves divine creations, and in the Middle Kingdom it was said that the first human (rmt, later $r m t$ ) was created from the tear (rmit) of the creator-god. ${ }^{22}$ Though this idea was associated with an explanation of the suffering of mankind it also gives an explanation of their origin. ${ }^{93}$ Another text implies that people are small livestock, i.e. merely cattle, the property of the gods. ${ }^{94}$ This view is the negative end of the scale from the title of the pharaoh as shepherd, the shepherd's crook being one of the earliest insignia of

88 Morenz, Egyptian Religion, 134.

89 There are also moral self-laudations in private autobiographies most often phrased as positive statements of good character and right action, see Lichtheim, Maat, 105. A thorough discussion of the Negative Confessions (103-144), and the moral vocabulary found therein (145-50) as well as the aspects of ma'at (151) and a ranking of virtues and vices (152-53) is also contained in Lichtheim's discussion.

90 See the discussion in D. Lorton, 'Legal and Social Institutions of Pharaonic Egypt', in Civilizations of the Ancient Near East, 1.355-60; and the Demotic texts in which there is the recurring phrase 'according to law'; see G. Mattha, The Demotic Legal Code of Hermopolis West (2 vols.; Cairo: Institut français d'archéologie orientale du Caire, 1977).

91 Lichtheim, Maat, 152. See also her discussion on Egyptian morals in a more recent study, Moral Values in Ancient Egypt (OBO 155; Vandenhoeck \& Ruprecht, 1997).

92 Morenz, Egyptian Religion, 183; Hornung, Conceptions of God, 150; cf. Lesko, 'Ancient Egyptian Cosmogonies and Cosmology', 101-102.

93 Baines, 'Society, Morality, and Religious Practice', 163; cf. also Morenz, Egyptian Religion, 183, and see p. 184 where the god Khnum's activity as creator is discussed.

94 Wilson, 'Egypt', 79. 
the pharaoh and the origin of one of the words meaning 'to rule'. .95 This is often a positive image due to its association with provision and protection.

An 'Egyptocentric' view was prominent in the thinking of the inhabitants of that nation which promoted them as the most important people on earth..$^{96}$ This was a result of their national religion, which had their people being ruled by a divine king. They held the conviction that their nation was the centre of the earth ${ }^{97}$ and that they were superior to all other peoples. ${ }^{98}$ Their self-worth seemingly was rooted in their religion and their belief that they held a position of privilege and status among their gods.

\section{Conflict between Deities}

Given the size of the pantheon in Egypt it is amazing that this issue is rarely seen. It is true that there are examples of conflicts between deities in Egyptian literature. Two of the most well known documents containing incidents of divine conflict are The Contendings of Horus and Seth ${ }^{99}$ and The Blinding of Truth by Falsehood. ${ }^{100}$ However these conflicts are between the gods, and humans do not play a role, nor do humans suffer as a result of these conflicts. Thus the issue of theodicy never arises in relation to conflict between the gods.

\section{Judgement in the Afterlife}

This, of course, is the main element of religion that negates the need for theodicy in Egyptian literature. Many of the specifics have already been covered above and need not be repeated here. Lest modern readers believe that the Egyptians were assured and comfortable with their official teachings, Lichtheim makes this observation:

But whatever apprehension of the judgment the Egyptian had, it was as nothing compared to his fear and hatred of death. By right doing and by ritual means as well, the judgment would be overcome. But death could not

95 Wilson, 'Egypt', 79.

96 Morenz, Egyptian Religion, 42-49. See also Wilson, 'Egypt', 33.

97 Morenz, Egyptian Religion, 42-47. This idea was not limited to the Egyptians. See the brief discussion of this motif in the OT in L.C. Allen, Ezekiel 1-19 (WBC 28; Dallas: Word, 1994), 72-73.

98 Morenz, Egyptian Religion, 47-49.

99 See Lichtheim, Ancient Egyptian Literature, 2.214-23, and the discussion in J.G. Griffiths, The Conflict of Horus and Seth (Liverpool: Liverpool University, 1960).

${ }^{100}$ See Lichtheim, Ancient Egyptian Literature, 2.211-14; and the summarising discussion in J. van Dijk, 'Myth and Mythmaking in Ancient Egypt', in Civilizations of the Ancient Near East, 3.1703-1706. 
be evaded. With all his faith in the magical manipulation of the universe, the Egyptian, when not indulging in hopes and phantasies, was a pragmatist. Death was a massive reality. The hereafter? Except in imaginative tales, no one had ever come back to tell of it. These two things remained largely unresolved: the full-bodied fear of death, and the nagging doubt about the reality of a life in the beyond. To overcome these two required not selfassertion but rather a self-restraining sagacity and piety:

The end of the man of god is to be buried on the mountain with his burial equipment (Papyrus Insinger 18, 12). ${ }^{101}$

\section{Comparison of Sumero-Babylonian Literature with Egyptian Literature}

Some comparisons of Sumero-Babylonian literature with that of Egypt regarding innocent suffering are now in order. 102

First, we can observe that theodicy, by strict definition, is not an appropriate category for discussion of Egyptian literature due to the Egyptian view of a judgement in post-mortem existence. This is in contrast to Sumero-Babylonian literature, which calls for the rectification of injustice and illness in the present life. To be sure, there are protests over injustices and bad treatment in Egyptian literature but the general tenor of Egyptian society was more serene, ${ }^{103}$ and the possibility of all things being set right in the afterlife made a difference in their outlook.

Secondly, the gods are not viewed in either literature as holding to as high a moral standard as, for example, that of Yahweh of the ancient Israelites. The gods of Egypt and Mesopotamia are not always portrayed in 'holy' terms, and in neither culture are moral standards based on the character of the gods. ${ }^{104}$ In Egypt, behavioural standards related to keeping $m a$ ' $a t$; in Mesopotamia the law codes were often based on economic factors, and wrongdoing was seen as an offence against society. The claim to 'righteousness' was usually based on ritual observations, especially in times of suffering when the supplicant was not able to get the god to reveal the reason for the divine anger expressed against the person.

101 Lichtheim, Maat, 144.

102 See my article 'Innocent Suffering in Mesopotamia', 193-214 for a discussion of this issue. The conclusions regarding Mesopotamia in this section come from that discussion.

103 Gladson, 'Retributive Paradoxes', 85.

104 Contrast with this the numerous claims of Yahweh's holiness, Lv. 11:44-45; $19: 2 ; 21: 8$; Jos. 24:19; 1 Sa. 2:2; etc., and the title 'Holy One of Israel' ascribed to Yahweh in Ps. 71:22; 78:4; Is. 1:4; 5:19, 24; 10:20; etc. 
Thirdly, in Egypt the gods are almost never questioned or blamed for injustices; in Mesopotamia, suggestions of a god or goddess being responsible for someone's suffering are rare and made in the most cautious terms. When it is claimed in the Admonitions of Ipuwer that the gods might be at fault the king responds with the conventional teaching that people have failed to keep $m a$ 'at, leading to the disruption of society. In Mesopotamia when a sufferer pleads for a god or goddess to relieve sickness or suffering there is almost always an assumption on the part of the petitioner that a sin of some kind has caused the deity to allow this treatment.

This leads to the fourth observation, that the source of evil in Egypt and Mesopotamia differed. For the Egyptians, evil was generally associated with isftt, 'disorder', the opposite of ma 'at. Those who did not do or speak according to the standards of $m a$ 'at allowed disorder into their lives. For the Mesopotamians evil was often seen as a result of demonic activity, hence a result of living forces or beings. Even a 'friendly' personal god may allow suffering to occur in an individual's life if offended, so the rituals in Mesopotamian worship often functioned as appeasement so that suffering was avoided or halted.

\section{Conclusion}

The results of this study have shown that theodicy does not and cannot exist in ancient Egyptian literature. The gods are not held responsible for human suffering in Egypt; therefore there is no need to defend divine justice. All human suffering, whether innocent or deserved, is seen as a result of the failure on the part of humans to observe $m a$ ' $a t$, the standard of fairness or veracity. Iśft, the opposite of $m a$ ' $a t$, is understood as disorder, chaos, or the like, and associated with suffering.

The main factor in Egyptian religion which negates the need for theodicy is, of course, their highly developed view of post-mortem existence. This is what allowed injustices in this life to be a less important issue, since the individual knew all things would be set right in the judgement. 